\title{
TEMPERATURE, SALINITY, PH, DISSOLVED OXYGEN AND NUTRIENT VARIATIONS AT FIVE STATIONS ON THE SURFACE WATERS OF ADMIRALTY BAY, KING GEORGE ISLAND, ANTARCTICA, DURING THE SUMMERS FROM 2009 TO 2012
}

http://dx.doi.org/10.4322/apa.2014.070

Mauro Juliano Cascaes ${ }^{1, *}$, Ana Cecilia Rizzatti de Albergaria Barbosa ${ }^{1}$, Felipe Sales de Freitas ${ }^{1}$, Fernanda Imperatrice Colabuono ${ }^{1}$, Josilene da Silva ${ }^{1}$, Vinícius Faria Patire ${ }^{1}$, Diego Barbosa Senatore ${ }^{1}$, Patrick Simões Dias ${ }^{1}$, Caio Vinícius Zecchin Cipro', Satie Taniguchi', Marcia Caruso Bícego', Rosalinda Carmela Montone ${ }^{1}$, Rolf Roland Weber ${ }^{1}$

'Oceanographic Institute, São Paulo University - USP, Praça do Oceanográfico, 191, sala 186, CEP 05508-120, São Paulo, SP, Brazil *e-mail:maurojuliano@usp.br

Abstract: Classic hydrographical parameters and dissolved nutrients were measured during the Antarctic summers from 2009 to 2012. Physical and biological processes control the nutrient levels in Admiralty Bay, as well as upwelling of deep water from Bransfield Strait. Additional data on summer land run-off and wind speeds and directions is needed to get a better model for the factors that control the primary production of the area.

Keywords: nutrients, $\mathrm{pH}$, dissolved oxygen, Antarctica

\section{Introduction}

Admiralty Bay is a well-studied marine sub Antarctic environment due to the five research stations (Poland, Brazil, Peru, Equator and U.S.A) established there since the sixties. Hydrographical studies of the area have been made since 1980 by scientists of the Polish Research Station of Arctowski (Pruszak, 1980; Lipski, 1987; Rakusa-Suszcewski et al., 1993) and Brazilians from the Ferraz Station (Brandini \& Rebello, 1994).

Further data of nutrients, dissolved oxygen (DO) and phytoplankton distribution were summarized by Weber \& Montone (2006). Although there is no scarcity of previous summer data, a coherent general pattern could not be observed due to strong yearly variations. This may reflect the irregular pattern of terrestrial ice melting and of the irregular land run-off contributions which are not quantified on a systematic basis.

The present study reports the temperature, salinity, dissolved nutrients, dissolved oxygen and $\mathrm{pH}$ variations during the summers of 2009/2010/2011/2012 (from OPERANTAR XXVII to OPERANTAR XXIX) in five points of Admiralty Bay near EAFC (Portuguese acronym for Comandante Ferraz Antarctic Brazilian Research Station) and Arctowski Research Stations at three depths.

\section{Materials and Methods}

The location of the Sampled Station areas is shown on Figure 1 and Table 1 . The water was collected at 0,15 and $30 \mathrm{~m}$ depth.

Water sampling was done with a peristaltic pump (Anauger 900 - flow rate of $1200 \mathrm{~L} \mathrm{~h}^{-1}$ at $30 \mathrm{~m}$ depth and $2.300 \mathrm{~L} \mathrm{~h}^{-1}$ at the sea surface) and the temperature was measured with temperature sensor (Seamon Mini) attached to the pump. The samples and the analysis of dissolved oxygen (DO), $\mathrm{pH}$, nitrite, nitrate, phosphate and silicate was done according Grasshoff et al. (1983). 


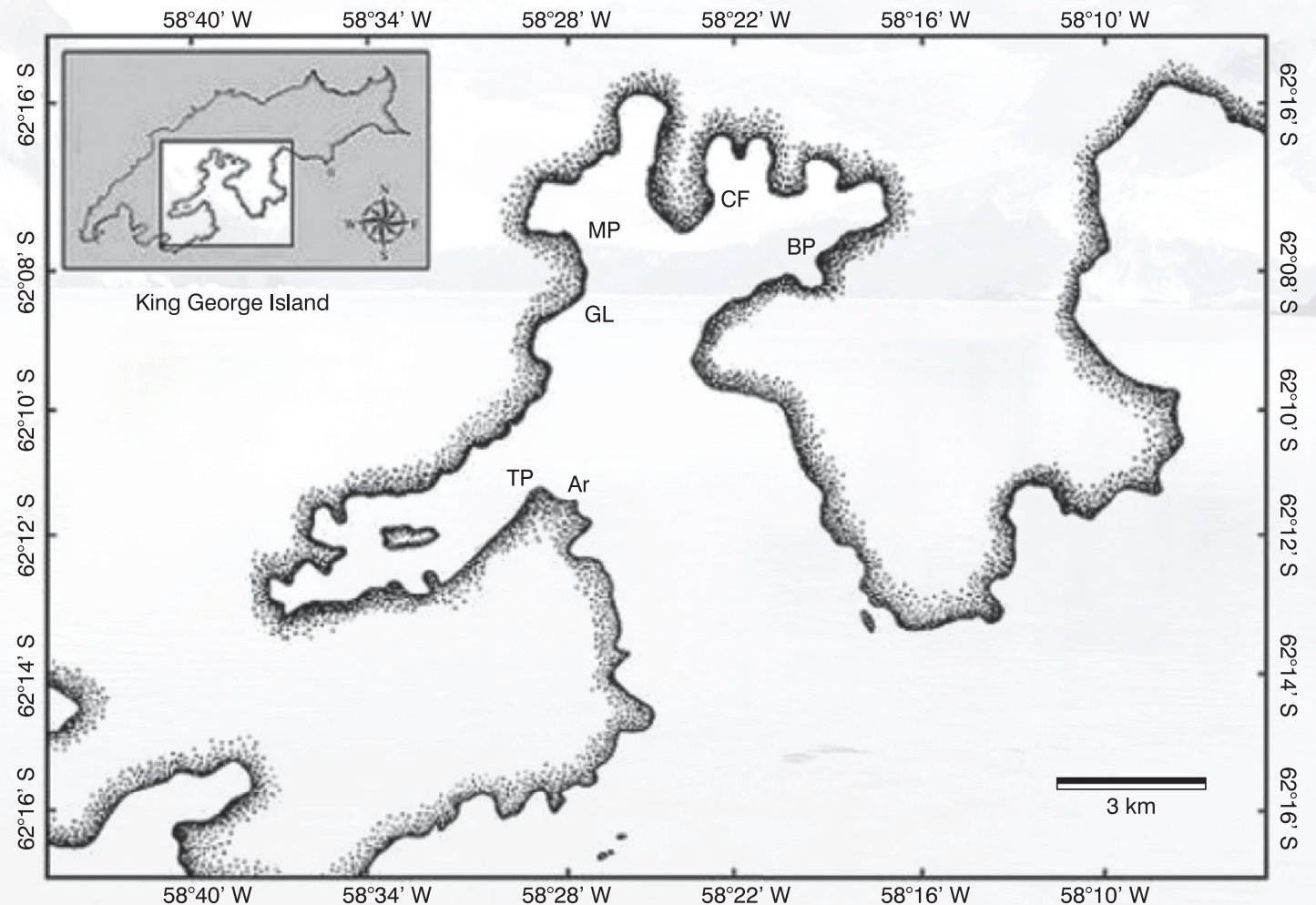

Figure 1. Map of Sampling Stations and their positions (CF: Comandante Ferraz; BP: Botany Point; MP: Machu Picchu; TP: Thomas Point; AR: Arctowski) (Coastline extractor - http:// http://www.ngdc.noaa.gov).

Table 1. Oceanographic parameters in Admiralty Bay.

\begin{tabular}{|c|c|c|c|c|c|c|c|c|c|c|}
\hline & \multicolumn{5}{|c|}{ OPERANTAR XXVIII } & \multicolumn{5}{|c|}{ OPERANTAR XXIX } \\
\hline & Phase & Average & S. d. & Min. & Max. & Phase & Average & $\begin{array}{l}\text { Standard } \\
\text { deviation }\end{array}$ & Min. & Max. \\
\hline \multirow[t]{2}{*}{ Temperature $\left({ }^{\circ} \mathrm{C}\right)$} & $1^{\text {st }}$ & 0.09 & 0.41 & -0.36 & 0.91 & $1^{\text {st }}$ & 0.84 & 0.46 & 0.24 & 1.54 \\
\hline & $3^{\text {rd }}$ & 0.82 & 0.15 & 0.52 & 1.02 & $3^{\text {rd }}$ & 1.62 & 0.12 & 1.48 & 1.77 \\
\hline \multirow[t]{2}{*}{ Salinity } & $1^{\text {st }}$ & 34.16 & 0.09 & 34.02 & 34.26 & $1^{\text {st }}$ & 34.17 & 0.11 & 33.94 & 34.35 \\
\hline & $3^{\text {rd }}$ & 34.09 & 0.11 & 33.89 & 34.18 & $3^{\text {rd }}$ & 34.12 & 0.12 & 33.93 & 34.23 \\
\hline \multirow{2}{*}{$\begin{array}{c}\text { Dissolved } \\
\text { Oxygen }\left(m L L^{-1}\right)\end{array}$} & $1^{\text {st }}$ & 7.06 & 0.29 & 6.46 & 7.43 & $1^{\text {st }}$ & 7.79 & 0.19 & 7.53 & 8.13 \\
\hline & $3^{\text {rd }}$ & 6.46 & 0.66 & 5.11 & 7.19 & $3^{\text {rd }}$ & 7.27 & 0.10 & 7.13 & 7.38 \\
\hline \multirow[t]{2}{*}{ pHs } & $1^{\text {st }}$ & 7.94 & 0.06 & 7.89 & 8.05 & $1^{\text {st }}$ & 7.88 & 0.06 & 7.81 & 7.98 \\
\hline & $3^{\text {rd }}$ & 8.04 & 0.02 & 8.01 & 8.06 & $3^{\text {rd }}$ & 7.71 & 0.05 & 7.66 & 7.76 \\
\hline \multirow{2}{*}{$\begin{array}{l}\text { Phosphate } \\
\left(\mu \mathrm{mol} \mathrm{L}{ }^{-1}\right)\end{array}$} & $1^{\text {st }}$ & 1.66 & 0.22 & 1.22 & 2.13 & $1^{\text {st }}$ & 1.96 & 0.56 & 1.11 & 2.50 \\
\hline & $3^{\text {rd }}$ & 1.76 & 0.16 & 1.49 & 2.07 & $3^{\text {rd }}$ & 1.79 & 0.18 & 1.59 & 2.09 \\
\hline \multirow{2}{*}{$\begin{array}{c}\text { Silicate } \\
\left(\mu \mathrm{mol} \mathrm{L}{ }^{-1}\right)\end{array}$} & $1^{\text {st }}$ & 41.77 & 0.56 & 40.89 & 42.81 & $1^{\text {st }}$ & 61.06 & 12.31 & 39.09 & 74.52 \\
\hline & $3^{\text {rd }}$ & 40.80 & 0.59 & 39.99 & 41.67 & $3^{\text {rd }}$ & 37.84 & 4.34 & 30.15 & 41.96 \\
\hline \multirow{2}{*}{$\begin{array}{c}\text { Nitrite } \\
\left(\mu \mathrm{mol} \mathrm{L}{ }^{-1}\right)\end{array}$} & $1^{\text {st }}$ & 0.06 & 0.03 & 0.00 & 0.11 & $1^{\text {st }}$ & 0.50 & 0.16 & 0.40 & 0.76 \\
\hline & $3^{\text {rd }}$ & 0.14 & 0.06 & 0.04 & 0.23 & $3^{\text {rd }}$ & 0.77 & 0.05 & 0.70 & 0.86 \\
\hline \multirow{2}{*}{$\begin{array}{c}\text { Nitrate } \\
\left(\mu \mathrm{mol} \mathrm{L} L^{-1}\right)\end{array}$} & $1^{\text {st }}$ & 16.52 & 1.65 & 13.86 & 19.80 & $1^{\text {st }}$ & 20.43 & 2.50 & 14.74 & 22.66 \\
\hline & $3^{r d}$ & 16.49 & 0.40 & 16.00 & 17.25 & $3^{\text {rd }}$ & 11.34 & 2.02 & 9.05 & 14.29 \\
\hline
\end{tabular}




\section{Results}

In Table 1 we show the oceanographic parameters in Admiralty Bay: temperature, salinity, dissolved oxygen, $\mathrm{pH}$, phosphate, silicate and nitrite. The table presents average, s.d., minimum and maximum of each phase.

Temperature differences were significant between November and March. In contrast, $\mathrm{pH}$ values also presented significant differences along the sampling periods, which were expected, but did not affect the $\mathrm{pH}$ values. For example, in the $3^{\text {rd }}$ Phase of OPERANTAR XXIX we had the lowest $\mathrm{pHs}$ although temperatures were at their highest.

First phases of OPERANTARES XXVIII e XXIX (between November and December) and 3rd phase OPERANTAR XXVIII (between January and February) show higher values without significant differences.

Our salinity and temperature is closer to the data of deeper water of Admiralty Bay (Lipski, 1987; Sarukhanyan \& Tokarczyk, 1988; Weber \& Montone, 2006).

Nitrate and nitrite also showed significant variations between the different sampling periods.

In the third phase of OPERANTAR XXVIII, phosphate concentrations were uniform during all phases of sampling.

\section{Discussion}

The upper mixed layer of Admiralty Bay is between 15 up to $35 \mathrm{~m}$ (Brandini, 1993). Vertical mixing is very intense so no stratification can occur (Prusza, 1980; Nedzarek \& RakusaSuszczewski, 2004).This study is limited to this upper layer, therefore a homogeneity of the hydrographical data along the water column is expected. Jażdżewski et al. (1986) showed that there was a uniform pattern of the hydrographical data between the different areas of Admiralty Bay.

An increase in temperature between the beginning and the end of Antarctic summer is normal (Brandini \& Rebello, 1994; Lange et al., 2006). Air temperature can oscillate from 0,5 up to $2,0^{\circ}$ Celsius in the summer (INPE, 2011). March of OPERANTAR XXVIII, however was anomalous. Instead of increasing as normally expected like in OPERANTAR XXIX, OPERANTAR XXVII it sinked from 0,8 to $0,2{ }^{\circ} \mathrm{C}$ (INPE, 2011).

As well as the temperature, $\mathrm{pH}$ values varied widely, but they have not always been correlated, as shown in Table 1 . $\mathrm{pH}$ is also influenced by photosynthesis or organic matter degradation. To be sure about the biological variables affecting $\mathrm{pH}$ it will be necessary to compare our data with the other data of Module 3 projects INCT-APA. Salinity (PSU) did not show significant differences in all sampling periods.

Lange et al. (2007), studying Admiralty Bay, reported an increase in temperature of the surface water but no salinity changes during the summer. We registered a small difference in salinity due to an iceberg positioned near Botany Point in the first phase of this OPERANTAR. Comparing our results with other authors who studied the area we can perceive differences. Salinity and temperature for instance are not the same as reported by other authors for the area.

WSW and NWN winds carry the surface waters of the inlet in the direction of the Bransfield Strait. This process creates an inflow of deep water to Admiralty Bay (Pruszak, 1980; Robakiewicz \& Rakuza-Swazcsewski, 1999). As this Bay is influenced by the water masses of Weddell Sea, colder and more saline (-0,75 C - 33,50 psu) and of the Bellinghausen Sea, warmer and less saline (2,25 C - 34,40 psu) (Weber \& Montone, 2006) a small upwelling on Admiralty Bay may occur.

Therefore our data has bottom water characteristics which is more evident when looking at the dissolved oxygen data whose values are close to the bottom water and lower than those of the surface waters (Samp, 1980; Rakusa-Suszczewski, 1995). The first phase of sampling on OPERANTAR XXIX presented the highest DO concentrations. The other samples showed lower dissolved oxygen levels. Oxygen levels are controlled by physical factors as well as affected by all biological processes of the water column of the study area. Silicate concentrations for the first phase of OPERANTAR XXIX were greater than the average value for all other phases (Table 1).

On this particular phase we observed a Pteropoda bloom, which may be associated with a higher availability of silicate. Pteropoda are plankton grazers eating mainly diatoms and dinoflagellates as well as small crustaceans (Boersma, 1978). Silicate is the limiting nutrient for diatoms growth. Increase of the diatom number may be associated with higher dissolved oxygen as pointed out before. To be sure of this correlation we had to integrate our chemical data with phytoplankton data form Module 3 studies. Higher silicate concentrations for the beginning of summer (first phase) may have been associated with the non utilization 
of silicate during the winter months due to the absence of light. Furthermore upwelling can occur in Admiralty Bay as shown by (Rakuza-Swazczewski, 1980) which enhances the silicate levels.

Significant variations of the parameters nitrite and nitrate were observed. High productivity in the first phase of OPERANTAR XXIX may be responsible for the high nitrite concentrations and low nitrate concentrations.

Many biological and physical variables affect the chemistry of the water column. To infer which processes predominate, it will be necessary to integrate our data with the other sub-projects of Module-3.

\section{Conclusions}

Sea surface temperature relates directly to air temperature. $\mathrm{pH}$ is related to air temperature and water temperature. Changes of $\mathrm{pH}$ between different phases of sampling was not associated with seawater temperature. There are occasional upwelling episodes near EACF and Arctowski Stations. Dissolved oxygen in seawater is related to primary productivity or strong wind fields.

\section{Acknowledgements}

This work integrates the National Institute of Science and Technology Antarctic Environmental Research (INCT-APA) that receive scientific and financial supports of the National Council for Research and Development (CNPq process: $\mathrm{n}^{\circ}$ 574018/2008-5) and Research Support Foundation of the State of Rio de Janeiro (FAPERJ $n^{\circ}$ E-16/170.023/2008). The authors also acknowledge the support of the Brazilian Ministries of Science, Technology and Innovation (MCTI), of Environment (MMA), Inter-Ministry Commission for Sea Resources (CIRM) and PROANTAR (Brazilian Antarctic Program).

\section{References}

Boersma, A. 1978. Foraminifera. In: HAQ, B. U.; BOERSMA, A. (eds.) Introduction to Marine Micropaleontology. New York: Elsevier/North Holland, p. 19-77. (está sem indicação pq não tem o ano, mas é essa que se refere ao Boersna, favor substituir);

Brandini, F.P. (1993). Phytoplankton growth in an antarctic coastal environment during stable water conditions - implications for the iron limitation theory. Marine Ecology. Progress Series, 93: 267-275.

Brandini, F.P. \& Rebello, J. (1994). Wind field effect on hydrograph and chlorophyll dynamics in the coastal pelagial of Admiralty Bay, King George Island, Antarctica. Antarctic Science, 6(4): 433-442.

Grasshoff, K.; Ehrhardt, M. \& Kremling, K. (1988). Methods of Seawater Analysis. Weihein: Verlag Chemie. 419 p.

Instituto Nacional de Pesquisas Espaciais - INPE. (2011). Available from: <http://www.inpe.br/antartica>. (accessed: 15 ago. 2011).

Jażdżewski K.; Jurasz W.; Kittel W.; Presler E.; Presler P. \& Siciński J. (1986). Abundance and biomass estimates of the benthic fauna in Admiralty Bay, King George Island, South Shetland Islands. Polar Biology, 6: 5-16.

Lange, P.K.; Tenenbaum, D.R.; Braga, E.L. \& Campos, L.S. (2007). Micro phytoplankton assemblages in shallow waters at Admiralty Bay (King George Island, Antarctica) during the summer 2002-2003. Polar Biology, 30: 1483-1492.

Lipski, M. (1987). Variations of physical conditions, nutrients and chlorophyll a contents in Admiralty Bay (King George Island, South Shetland Islands, 1979). Polish Polar Research, 8(4): 307-332.

Nedzarek, A. \& Rakusa-Suszczewski, S. (2004). Decomposition of macro algae and the release of nutrients in Admiralty Bay, King George Island, Antarctica. Polar Bioscience, 17: 16-35

Pruszak, Z. (1980). Current circulation in the waters of Admiralty Bay (region of Arctowski Station on King George Island). Polish Polar Research, 1: 55-74.

Rakuza-Swazczewski, S. (1980). Environmental conditions and functioning of Admiralty Bay (South Shetland Islands) as part of the Nearshore Antarctic Ecosystem. Polish Polar Research, 1: 11-27. 
Robakiewicz, M. \& Rakusa-Suszczewski, S. (1999). Application of 3D circulation model to Admiralty Bay, King George Island, Antarctica. Polish Polar Research, 20: 43-58.

Rakusa-Suszczewsky, S.; Mietus, M. \& Piasecki, J. 1993. Weather and Climate. In: Rakusa-Suszczewsky, S. (Ed.), The Maritime Antarctic Coastal Ecosystem of Admiralty Bay, Varsóvia: Polish Academy of Sciences, p. 19-25.

Samp, R. (1980). Selected environmental factors in the waters of Admiralty Bay (King George Island, South Shetland Islands) December 1978 - February 1979. Polish Polar Research, 1: 53-66.

Sarukhanyan, E.J. \& Tokarzykr, R. (1988). Coarse-Scaleh hydrological conditions in Admiralty Bay, King George Island, West Antarctica, Summer 1982. Polish Polar Research, 9: 121-132.

Weber, R.R. \& Montone, R.C. (2006). Gerenciamento ambiental na Baía Do Almirantado (Relatório da Rede 2). 259 p. 